\title{
The Embryo Pancreas is a Source of Increased Yolk Amylase in the Fertilized Eggs of Domestic Fowls
}

\author{
Takeyuki IKENO, Hideki SAKAMOTO*, Kumiko IKENO**, \\ and Katsumi NIWA*** \\ Department of Oral Biochemistry, School of Dentistry, Ohu University, Tomita-machi, \\ Koriyama-shi, Fukushima 963, *Fukushima Prefectural Poultry Experiment \\ Station, Mansuida, Tomita-machi, Koriyama-shi, Fukushima 963, \\ ** Department of Hospital Pharmacy, Scool of Dentistry, Ohu \\ University, Tomita-machi, Koriyama-shi, Fukushima 963, and \\ *** Department of Dental Radiology, Scool of Dentistry, Ohu \\ University, Tomita-machi, Koriyama-shi, Fukushima 963, Japan
}

(Received 19 April 1991/Accepted 30 July 1991)

\begin{abstract}
The amylases were studied in the yolk of fertilized eggs and in the pancreases of the embryos of domestic fowls. The amylase activity in the yolk increased markedly from 13 days of incubation until hatching, but the activity decreased when the embryos were taken out of the eggs. The isoamylases in the yolk and in the pancreas of the embryo were identical electrophoretically. The amylase occurs mainly in the pancreas of the embryo. We think that the increase in amylase activity in the yolk of fertilized eggs during incubation depends upon the accumulation of pancreatic amylase synthesized by the developing embryo in the egg. - KEY WORDS : amylase, development, domestic fowl, pancreas, yolk
\end{abstract}

We investigated the developmental changes of amylase activities in the yolks of fertilized eggs and in the embryos of domestic fowls [2]. As the embryo develops, the amylase activity increases markedly not only in the pancreas of the embryo but also in the yolk of the fertilized egg. And the amylase in the yolk is electrophoretically the same as that in the pancreas of the embryo at 15 or 21 days of incubation. The amylase appeared in the egg yolks at 1 day of incubation and the activity in the embryo was detectable at 6 days. The amylase increased in both the pancreas and the yolk (especially after 13 days of incubation) according to the development of the embryo. The increase in yolk amylase after 13 days of incubation apparently depended on the enzyme synthesis in the pancreas of the embryo.

In this paper, we describe the source organ which increases with incubation the amylase in the yolk of the fertilized eggs of domestic fowls.

\section{Materials and Methods}

Fertilized eggs from the Rhode Island Red breed were incubated in an incubator (MIC-72 $\mathrm{S}$, Murai, Nagoya) at $37.5^{\circ} \mathrm{C}, 60 \%$ relative humidity, and were turned hourly during 1 to 19 days of incubation. The eggs were transferred into a hatcher (MIC-72 H, Murai, Nagoya) for three more days of incubation. Every day ten to twelve eggs were taken from the incubator or the hatcher and used for experiments. After drilling of the blunt end of the eggshell under sterile conditions, the umbilical artery and vein connecting the yolk to the embryo were ligated and the embryo (14, 17 and 20 days old) was carefully removed from the egg. Then the eggs were covered with plastic wrap and operated eggs were iuncubated again in a hatcher without turning.

In some eggs, the yolk together with the yolk sac was separated, weighed and then homogenized in $10 \mathrm{ml}$ of saline. The pancreases of the embryos were excised and homogenized 


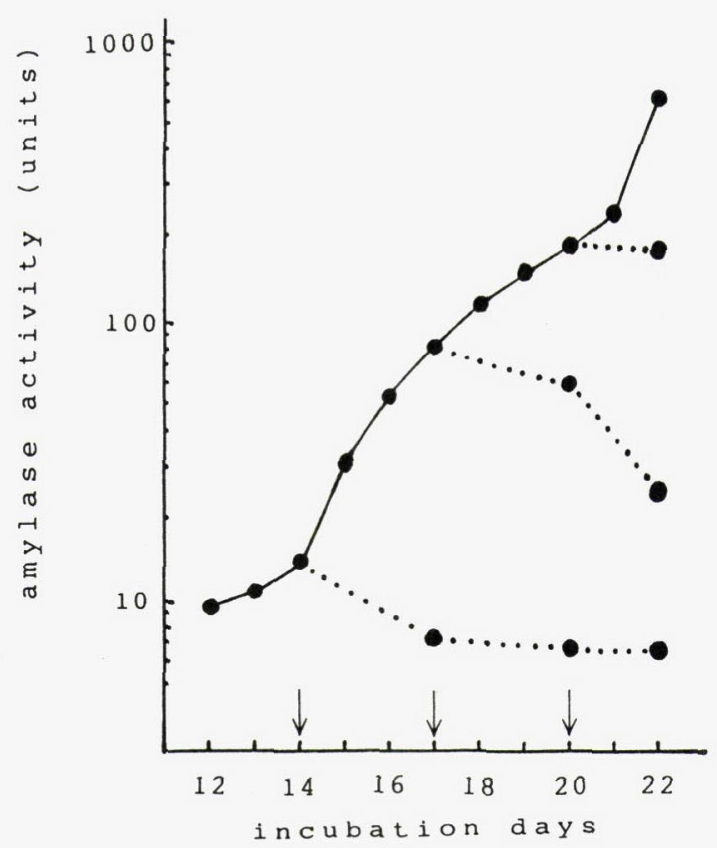

Fig. 1. Developmental changes of amylase activity the yolk of a fertilized domestic fowl egg. Arrows indicate the days the embryo was removed from the developing egg. normal (non-operated) yolk … : operated yolk

in $20 \mathrm{ml}$ of saline. Some organs were excised from 17-day-old embryos and homogenized separately in $2 \mathrm{ml}$ of saline. The homogenates were used to measure the amylase and to separate isoamylases by gel electrophoresis. The method of assaying amylase activity has been described [1]. All data were statistically analyzed by Student's $t$ test. The isoamylases in the yolk of a fertilized egg and the embryo organs were separated by the horizontal acrylamidegel electrophoresis described previously [4]. The amylase activity on the gel was detected by the iodine-starch reaction. The protein was measured using bovine serum albumin as a standard [3] .

\section{Results}

The amylase activities in the yolk of a fertilized egg after excision of the embryo are shown in Fig. 1. The amylase activity in the yolk at 14 days of incubation was $13.5 \pm 2.6$ units $/ g$ of yolk or $0.108 \pm 0.011$ units $/ \mathrm{mg}$ of

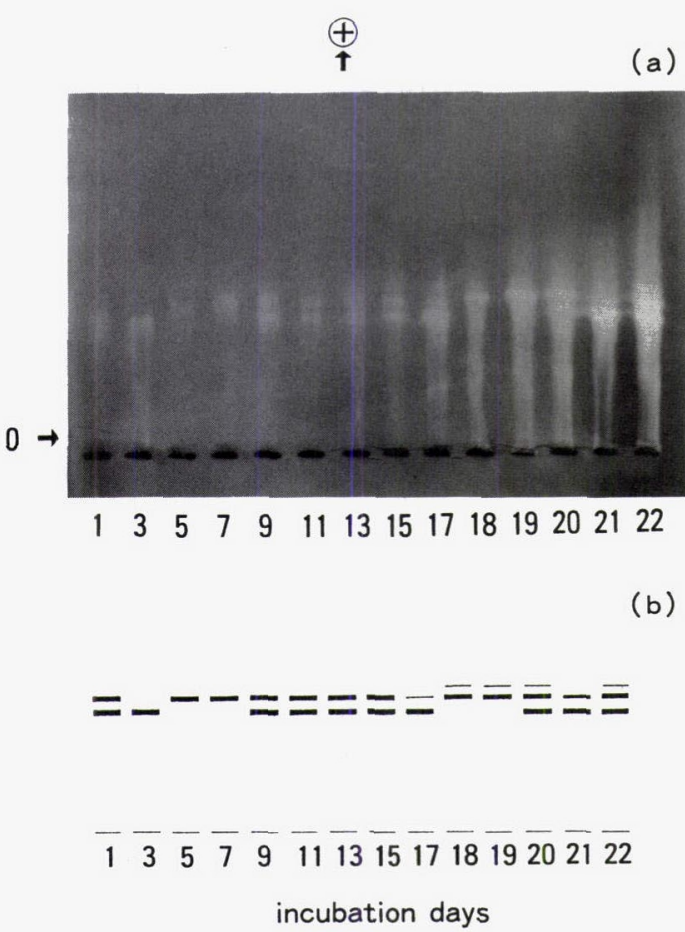

Fig. 2. Electrophoretic patterns of isoamylase in normal fertilized egg yolk relative to incubation time (a), and a diagrammatic illustration (b)

protein. Thereafter the activity in the yolk of non-operated fertilized eggs increased markedly until hatching. But the amylase activity in the yolk of an operated egg (no embryo) did not increase with incubation. The amylase activity in the yolk (especially operated eggs at 14 or 17 days of incubation) decreased markedly with additional incubation (from 0.108 units $/ \mathrm{mg}$ of protein to 0.054 units $/ \mathrm{mg}$ of protein at 17 days, to 0.043 units $/ \mathrm{mg}$ of protein at 20 days, to 0.026 units $/ \mathrm{mg}$ of protein at 22 days in the yolk operated at 14 days incubation and from 0.617 units/mg of protein to 0.380 units/mg of protein at 20 days and to $0.102 \mathrm{units} / \mathrm{mg}$ of protein at 22 days in the yolks operated at 17 days of incubation). Amylase activities in the yolks of operated eggs (14, 17 or 20 days old) are significantly lower than the activities in the yolk of non-operated egg during the additional incubation period $\mathrm{p}<0.01$.

Figure 2 shows the electrophoretic patterns of amylases in yolks of fertilized eggs after 

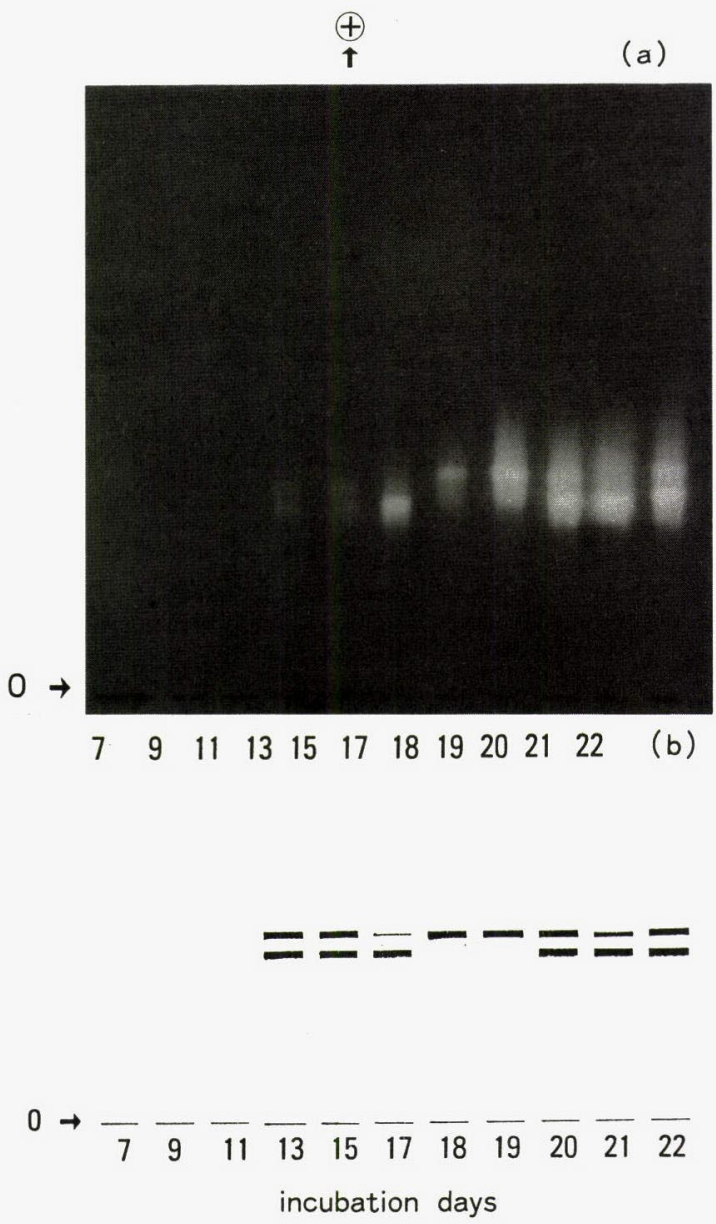

Fig. 3. Electrophoretic patterns of isoamylase in the pancreas of the embryo accoring to incubation time (a), and a diagrammatic illustration (b)

incubation. The amylases were clearly detected in the yolks during the whole period of incubation ( 1 to 22 days of incubation). In the early developmental stage, one or two isoamylases appeared, and two or three isoamylases appeared in the yolks at 20 and 22 days of incubation.

Figure 3 shows the amylase patterns in the pancreases of chick embrys. Amylase appeared in the embryos older than 13 days of incubation. The electrophoretic changes of major isoamylase patterns in the pancreases of the embryos were almost the same as those in respective yolks (each sample of the pancreas and the yolk was prepared from the same egg).

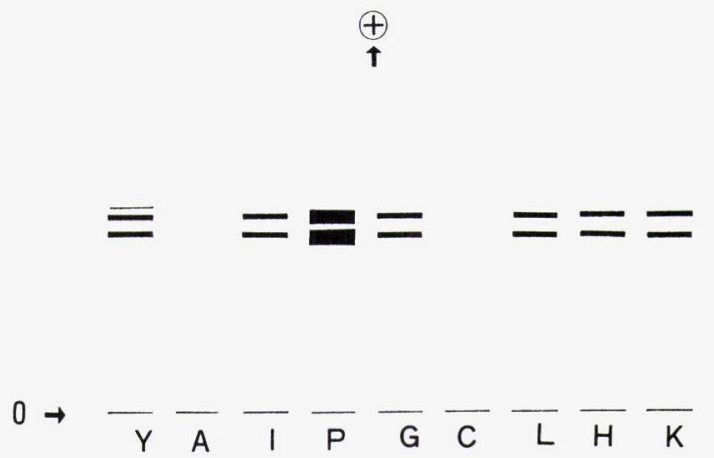

Fig. 4. Diagrammatic illustration of electrophoretic patterns of isoamylases in the organs of 17-day-old embryo. Samples Y : yolk (diluted 10 times with saline), $\mathrm{A}$ : albumen $\mathrm{I}$ : intestine $\mathrm{P}$ : pancreas $\mathrm{G}$ : gizzard $\mathrm{C}$ : content in the gizzard $\mathrm{L}$ : liver $\mathrm{H}$ : heart $\mathrm{K}$ : kidney

The distribution of amylases in organs of a chick embryo is shown in Fig. 4. High amylase activities were detected mainly in the pancreas, and low in the intestine, gizzard, liver, heart and kidneys. But amylase was undetectable in the samples of the albumen and the content of the gizzard. The electrophoretic patterns of the isoamylases in organs prepared from one embryo were quite similar.

\section{Discussion}

A complete culture system for the chick embryo has been developed [6]. It is possible to manipulate ova to hatching and maturity. And many experiments concerning morphological and biochemical changes appearing in the embryos have been reported $[5,7]$. But little is known about the relationship of amylase in the yolk and the embryo during development.

The amylases were observed in the yolks of the fertilized eggs of domestic fowl [2] . One of the mechanisms for the increase in the amylase activity in the yolks of fertilized eggs with incubation may be an accumulation of amylase protein synthesized by the yolk. Another possible mechanism is the conversion of inactive amylase to active amylase by incubation. We previously speculated that the pancreatic amylase in the embryo might be accumulated partially in the yolk of the egg during the developmental period [2]. Excision 
of the embryo from the developing egg markedly decreased the amylase activity in the yolk during incubation (Fig. 1). This clearly indicates that amylase protein is synthesized in the embryo, not in the yolk (sac) during the incubation period. Electrophoretic patterns of major amylases in the yolk and the pancreas of embryos indicated the identity of amylases in both the yolk and the pancreas (Figs. 2, 3 and 4 ).

We assayed amylase activity in some organs of 17-day-old embryos. Amylase was detected in the pancreas (194.2 units/whole pancreas), the intestine ( 5.72 units/whole intestine), the gizzard (1.76 units/whole gizzard), the liver (1.14 units/whole liver), the heart ( 0.96 units/ whole heart) and the kidney ( 0.78 units/whole kidney). The yolk amylase at 17 days of incubation was 1153 units/whole yolk. These results clearly show that pancreatic amylase in chick embryos is accumlated partially in the yolk during development.

We can say that the pancreas of a chick embryo is a source organ to make high amylase activity in the yolk of a fertilized egg during the later period of incubation. The amylase activity in the yolk of operated eggs was decreased by additional incubation especially in eggs operated at 14 or 17 days (Fig. 1). This may indicate that pancreatic amylase accumulated in the yolk is inactivated continuously, and then the amylase decreases. We found that not only amylase but also proteases in the pancreas of chick embryo might be accumulated in the yolk according to the development (data not shown). We do not know why amylase appears in the yolk in early incubation period and in unfertilized eggs. Determination of amylase distribution in the yolk and observation of yolk formation in the ovary of a hen may give some informations.

We found some variations of isoamylases in the yolk and the pancreas. It is not clear whether the variations depend upon the incubation periods or simply individual variation, so-called polymorphism. Variations of isoamylase in the yolk were identical to those of the pancreatic isoamylase on respective days (Figs. 2 and 3). Polymorphism of amylase in the pancreas and the serum of the Japanese quail [10], guineal fowl [8] and domestic fowl [9] are reported. Relationships of isoamylase patterns in the yolks, the pancreas and the serum of fertilized eggs or the embryos and analysis of polymorphism of amylase need further study.

\section{References}

[1] Ikeno, T., Matsushima, Y., and Ikeno, K. (1988). Electrophoretic behavior of amylase in mouse : The parotid gland is major source of serum amylase. Exp. Anim, 37, 275-278.

[2] Ikeno, T. and Ikeno, K. (1991). Amylase activity increases in the yolk of a fertilized egg of domestic fowl by incubation. Poultry Sci, in press

[3] Lowry, O. H., Rosebrough, N. J., Farr, A. L., and Randall, R. J. (1951) Protein measurement with the Folin phenol reagent. J. Biol Chem 193, 265-275.

[4] Matsushima, Y., Ikeno, T., Ikeno, K., and Tanaka, S. (1990). An electrophoretic polymorphism in salivary amylases (Amy-1) of mastomys (Praomys coucha). Lab. Anim, 24, 308-312.

[5] Miura, K., Sueyoshi, M., Jinbu, M., and Oka, M (1991). Chick embryo culture using duck egg shell -First successful hatch-. Exp. Anim, 40, 251-254.

[6] Perry, M. M. (1988). A complete culture system for the chick embryo. Nature, 331, 70-72.

[7] Rowlett, K. and Simkiss, K.(1987). Explanted embryo culture : in vitro and in viwo techniques for domestic fowl. British Poultry Sci, 28, 91-101.

[8] Shiraishi, K., Watanabe, S., Shibata, T., and Hirai, Y. (1978). Genetic polymorphism of serum albumin and serum amylase isozyme in the guinea fowl. Jpn. Poultry Sci, 15, 302-307.

[9] Tanabe, Y., Sugiura, S., and Fujioka, K. (1977). Studies on the phylogenic relationship of the Japanese native fowl breeds 2 . Genetic polymorphism of plasma amylases and transferrins. Jpn. Poultry Sci, 14, 173-178.

[10] Watanabe, S., Yoshida, H., and Kawahara, T.(1975). Serum amylase isozymes in the Japanese quail. Jpn. Poultry Sci, 12, 67-70. 
ニワトリ受精卵の卵黄中のアミラーゼは 発生胎仔の膵缄から由来する

池野武行 ·坂本秀樹* ·池野久美子** . 丹羽克味***

\author{
奥羽大学歯学部口腔生化学講座 \\ *福島県養鷍試験場 \\ **奥羽大学歯学部附属病院薬局 \\ ***奥羽大学歯学部歯科放射線学講座
}

ニワトリの受精卵を材料にして, 胎仔発生にともなら 卵黄中ならびに膵荿中のアミラーゼを観察して卵黄中の アミラーセ活性の增加する機構を明らかにする目的で実 験を行った。躬卵開始13日目から軼化までの間, 卵黄中 のアミラーゼ活性は影著に增加したが, 卵から発生胎仔 を摘出するとそれ以後, 卵黄中のアミラーゼ活性は低下 した。アクリルアミドゲル電気泳動像の分析から卵黄ア
ミラーゼと膵蔵アミラーゼとは同一であると観察され た。胎仔の臓器を材料にしてアミラーゼ活性を測定する と,アミラーゼは主に膵臓に局在していた。以上の結果 から，邲卵日数にともなら卵黄中のアミラーゼの活性增 加は, 胎仔膵臓で産生されたアミラーゼが卵黄中に蓄積 されるためにおこると考えられた。 